\title{
Tropicality of Colonial Heritage Buildings in a Deltaic Landscape: British Colonial Architecture in Khulna
}

\author{
Muhaiminul Islam \\ https://orcid.org/0000-0001-8402-5472 \\ Northern University of Business and Technology Khulna, Bangladesh \\ Hasan Muntasir \\ https://orcid.org/0000-0001-5669-1064 \\ Northern University of Business and Technology Khulna, Bangladesh
}

\begin{abstract}
During the $17^{\text {th }}-18^{\text {th }}$ century colonial period on the Indian subcontinent, British colonial architecture flourished - including in the Bengal Delta. Although colonial architecture was inherently different from the traditional architecture of this tropical region, the monsoon climate and deltaic landscape forced colonial style buildings to incorporate a number of tropical architectural features to ensure climatic comfort. In the contemporary period, due to pressure from population density, many colonial buildings have been demolished and replaced with multistory buildings. However, the tropical forces of this deltaic region need to be evaluated in order to re-create climate responsive architecture. This study aims to identify tropical architectural features inherent within colonial buildings of Khulna, Bangladesh, a city which formed a junction in the deltaic region during the colonial period. Four colonial buildings have been selected as case studies: two residential buildings, one mixed-use building, and a school. Tropical features were analysed from photographic data, and reproductions of plans and sections of the selected buildings, in order to reveal the significant tropical architectural features of these colonial period buildings. The case studies reveal structural and design elements that aided ventilation and air flow, and controlled solar radiation, humidity and driving rain. The findings aim to encourage practicing architects to rethink climate responsiveness in contemporary buildings in Bangladesh, by revealing how, a century ago, colonial buildings were influenced by the tropical deltaic climate, which impacted foreign architectural ideology and practice.
\end{abstract}

Keywords: Tropicality, Colonial Architecture, Deltaic Landscape, Architectural Heritage, Urbanisation, Khulna, Bengal

eTropic: electronic journal of studies in the tropics publishes new research from arts, humanities, social sciences and allied fields on the variety and interrelatedness of nature, culture, and society in the tropics. Published by James Cook University, a leading research institution on critical issues facing the worlds' Tropics. Free open access, Scopus Listed, Scimago Q2. Indexed in: Google Scholar, DOAJ, Crossref, Ulrich's, SHERPA/RoMEO, Pandora. ISSN 1448-2940. Creative Commons CC BY 4.0 free to download, save and reproduce. To cite, include: Author(s), Title, eTropic, volume, issue, year, pages and DOI: http://dx.doi.org/10.25120/etropic.19.2.2020.3762 
eTropic 19.2 (2020) Special Issue: Sustainable Tropical Urbanism

\section{Introduction}

7 ropical architecture can be specified as a scientific approach to building design applied around the earth's geographic belt between the tropics of Cancer and Capricorn. Most countries of the Tropics have experienced a European colonial history (Jackson, 2013). According to some scholars, a tropical approach to architecture became renowned during the post-World War II period when modern masters were invited to design identical buildings in newly independent nations (Atkinson, 1969, p. 554). This architectural approach became institutionalised as a body of knowledge by the mid twentieth century (Chang \& King, 2011; Chee et al., 2011; Chang, 2016; Jackson, 2013). In the 1950s the ideology further flourished when local architects started practicing in their home regions after receiving training from the UK, Australia and the USA where several courses had been introduced relating to tropical architecture (Shannon, 2014). However, the initiation of this notion occurred long before the post-WWII era, and according to many researchers the roots of tropical architecture derived mainly from the colonial age (Jackson, 2013, Chang, 2016). Atkinson specified a rise of "tropicalized" architecture around the 1820s (1969, p.547).

Climate has been a major force behind the origin of tropical architecture. Europeanstyle colonial buildings were challenged by the climate of the world's tropical regions. According to Koenigsberger et al. (1975), warm and hot temperatures are the major problem for architecture in the tropics where the annual mean temperature is higher than $20^{\circ} \mathrm{C}$. Thus, the idea of "tropicality" evolved with the need to respond to tropical climates by adapting European colonial buildings through consideration of architectural elements including the building envelope, windows, shading devices and more (Chang, 2016). The map in Figure 1 shows the tropical belt and regions that were subjected to British colonial rule. The map also indicates the GangesBrahmaputra deltaic territory of the Bengal Basin, an area of specific geographic and climatic consideration within the tropics.

As with other tropical regions, colonial buildings also faced climatic challenges in the Bengal delta region. The architectural styles the British had practiced in their homeland based on temperate climatic considerations were not applicable to this tropical deltaic environment (Kramer, 2006). Moreover, the monsoonal climatic contexts of this delta region are also different from other tropical climate areas, such as those classed as hot dry or warm humid (Koenigsberger et al., 1975). As a result of this climate, colonial architects had to adopt new building practices. However, as a Colonial ruler the British could not directly adopt vernacular dwelling systems, for their intention was to show Britain's imperial power (Metcalf, 1989). Consequently, on the Indian subcontinent a gradual hybridization occurred by mixing imperial outlook with climatic considerations, 
eTropic 19.2 (2020) Special Issue: Sustainable Tropical Urbanism

traditional architectural styles and emotional aspects of local buildings, to generate a new style of architecture known as the Indo-Saracenic, also referred to as the IndoGothic (Adnan \& Islam, 2018, p. 318). While this architectural style is famous for blending 'grand' elements from various previous empires - such as European and Mughal - in the Bengal deltaic regions this form of architectural "grandness" could not be practiced due to the climate. Instead, details and local motifs were chosen and incorporated into colonial buildings. From the imperial perspective this process acted to contextualise their power while appealing to the emotions of the local people.

Eventually, according to Adnan and Islam (2018), this hybrid style became famous in Bengal and was adopted by local elites. The city of Khulna, being geographically close to the first capital of the British Indian empire, Kolkata (Calcutta), and located on an important river junction experienced the building of such colonial Indo-Saracenic style establishments. This research paper examines four case studies of colonial buildings in Khulna with the aim of identifying their climatic adaptation features.

Figure 1. Location of Bengal Delta in the Tropics and regions under British colonialism

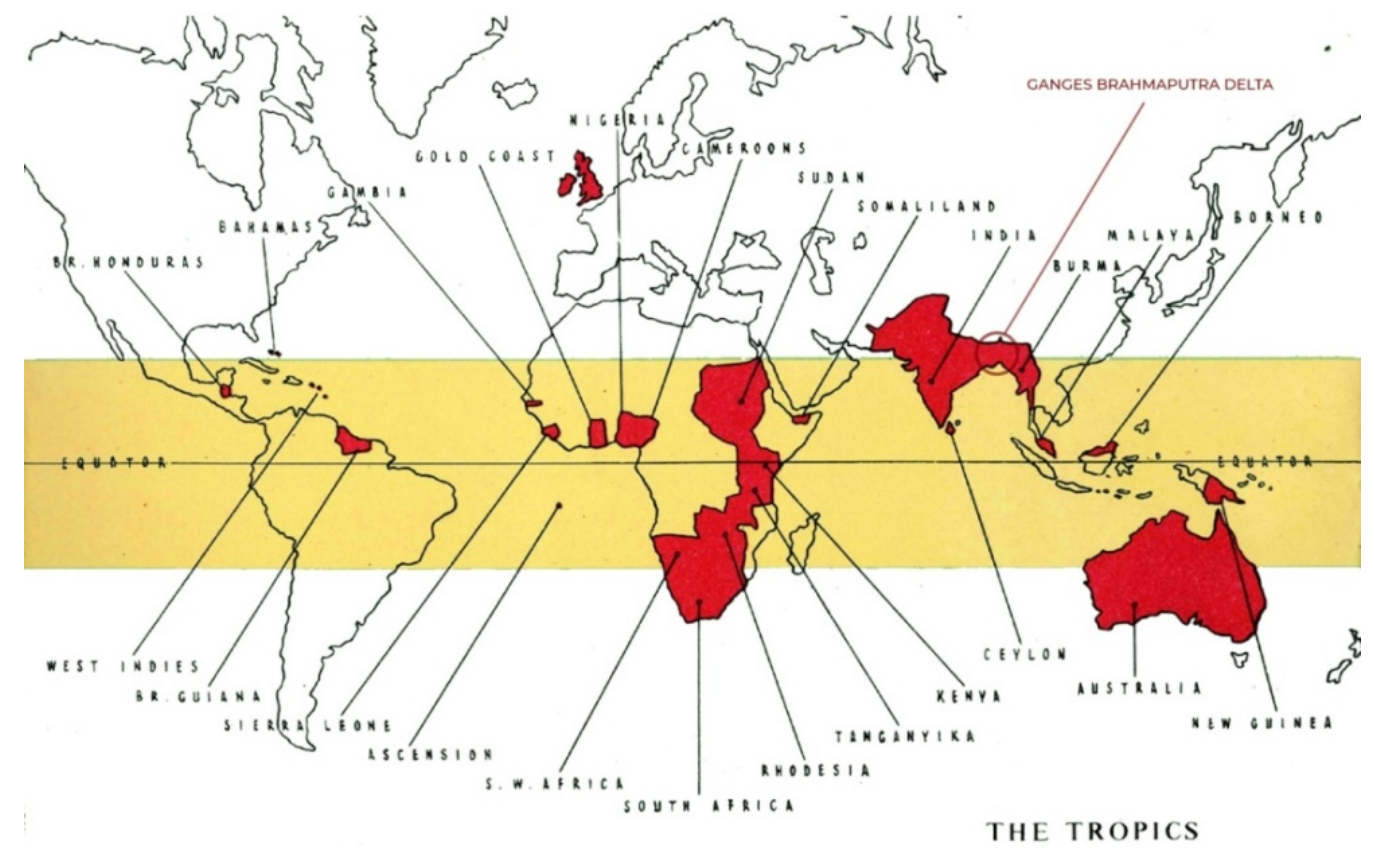

Source: Adapted from Fry \& Drew 1947 reproduced in Jackson, 2013.

Many researchers have undertaken studies to identify climatic design considerations embedded within historic architecture as this knowledge is useful in order to fuse those design elements with modern technologies. Much of this research has focused on vernacular and traditional architectural projects within regional and cultural contexts, for example: Indonesia (Hildegardis et al., 2019), Malaysia (Kubota \& Toe, 2015; 
Lundberg, 2008), Nepal (Bodach et al., 2014), Kerala, India (Dili et al., 2010), the North Eastern region of India (Singh et al., 2011), Bangladesh (Fatemi \& Islam, 2011), and Sylhet city in Bangladesh (Sobhan et al., 2013), among many more. As colonial buildings of the tropical regions likewise faced climatic challenges, and adapted to them through innovative solutions, some researchers have undertaken to identify these architectural responses in tropical locations such as North Queensland, Australia (Naylor, 2010), Surabaya, Indonesia (Antaryama et al., 2018) and Malaysia (Sanusi et al., 2019), among others. Studies of colonial buildings in the Bangladesh region have focused on various issues, for instance, Adnan and Islam (2018) have focused on colonial architectural features, while Nargis et al. (2015) have reviewed the architectural styles of colonial buildings. However, study of these rich colonial buildings from a climatic point of view is rare within the context of Bangladesh. More specifically, in the city of Khulna, Rahaman (2008) has worked on digital methods to conserve the legacy of colonial architecture, and Mridha and Khan (2004) have documented several important colonial buildings with the intention of mapping them in order to geographically define a colonial enclave within Khulna city. This paper adds to this research by examining colonial buildings of Khulna from a climatic point of view in order to discern their adaptation techniques in response to the specific climate of this tropical deltaic region.

The major objective of this study is to identify architectural features which are responsive to the tropical climate in the colonial buildings of Khulna. Firstly, a brief colonial architectural history of Bengal is outlined in order to present the approaches of Colonial architects in this tropical deltaic context. This is followed by a section on the Bengal deltaic climate which discusses its uniqueness and how it challenged the colonials to rethink architectural elements. Then a section on the colonial enclaves of Khulna presents a spatial overview to locate the British colonial territories of the city. Based on previous literature and physical on-site visits, a map is reproduced which outlines a location incorporating more than 50 potential colonial buildings in Khulna. In the methodology section, we elaborate the study framework and explain how the four buildings were selected as case studies for observing their climate responsive features. An observation framework has been re-created based on previous studies in order to investigate these architectural features. Finally, the findings section discusses the features which were found in the case studies. All key findings, including climate responsive design features and the considerations behind them, have been summarised in a table. 
eTropic 19.2 (2020) Special Issue: Sustainable Tropical Urbanism

\section{Bengal Delta: A brief Colonial Architectural History and Climatic Features}

\section{Colonial Architectural History in the Bengal Delta}

British colonial history of the whole Indian subcontinent started in the Bengal Delta region. Calcutta (Kolkata), the first colonial capital was established in 1773 on the banks of the river Hoogly, first under the rule of the British East India company and later transferred to the British Crown. The city continued to serve as the capital of the British Raj until 1912 when the capital was moved from Calcutta in Bengal to Delhi, India. Colonial architecture, as a particular style, rapidly flourished under British rule (Kramer, 2006). Early colonial buildings were in the Neoclassical or European Renaissance style as this was the most practiced architectural form across Europe at the time (Adnan \& Islam, 2018). The introduction of this new style of architecture aimed to present Britain's superiority in the deltaic context of Bengal (Afzal, 2018). However, with the passage of time changes occurred in the vocabulary of colonial architecture as the architectural heritage of the subcontinent began to influence colonial architecture.

Thus, besides importing European architectural expressions, during the late $18^{\text {th }}$ and early $19^{\text {th }}$ century, colonials also produced hybrid architectural styles by mixing local features with European elements. This new hybrid style picked Mughal architectural features such as domes, arches, chhatris at roof corners, thin columns at corridors, projecting façades, cornices, screen walls, plant inspired foliated decorative motifs etc. (Nargis et al., 2015) and mixed them with triangular pediments over Corinthian, Ionic or Doric columns; battlement parapets; molded plinths; rusticated walls and more (Adnan \& Islam, 2018). The hybrid style that incorporated both Indian and European features is known as the Indo-Saracenic. In Bengal the Curzon Hall is a prominent example of this style. The High Court building also contains some Mughal features, although European features are more prominent in this project (Nargis et al., 2015).

Besides broadly mixing Indian architecture with Neoclassical stylistic elements, the Bengal Delta also made specific contributions in the creation of a new architectural style. The most noteworthy colonial architectural innovation originating from the Bengal Delta is the "Bungalow" residential building which was adapted from the local vernacular low thatched house design and then adopted by the British as colonial residential buildings across all India (Adnan \& Islam, 2018). Ching (2017) in his book on global architectural history clarifies that this bungalow style was furthermore exported from Bengal to almost all British colonies, and thus became prevalent in tropical countries as well as being adopted back in the imperial homeland of England and spreading to America and other western countries. 
eTropic 19.2 (2020) Special Issue: Sustainable Tropical Urbanism

By the end of $19^{\text {th }}$ century local elites started to adopt British lifestyles and their colonial architectural design features as well (Adnan \& Islam, 2018). As a result, colonial buildings are found in almost every district city of Bangladesh, including many examples in the city of Khulna.

\section{Unique Climatic Challenges of Bengal Delta}

As articulated by Atkinson (1953), tropical climatic zones can be classified into three major groups based on the two most dominant climatic factors of temperature and humidity: warm humid climate, hot dry climate, and composite or monsoon climate. According to Koenigsberger et al.'s work based on Atkinson's classification, the Bengal delta falls under the monsoon or composite climatic zone. In this zone seasonal variations are higher. In the Koenigsberger et al. manual of tropical housing and building about three seasons within the composite or monsoon climate are assumed, however, more variations are also possible in the Bengal deltaic region. Patra and Bhaskaran (2016) have considered four seasonal periods when assessing trends of wind pattern over Bengal. On the other hand, in hot dry or warm humid climatic zones seasonal variations are negligible (Koenigsberger et al., 1975, p. 44). As a result, the climatic variations experienced in the deltaic region demand specialised architectural solutions.

The primary climatic threat for European colonials in Bengal was the temperature of the region. Whereas the average highest temperature of their home region was not more than $18^{\circ} \mathrm{C}$ (assumed based on weather data of recent times), in Bengal, the average highest temperature of the warmest month of April was over $30^{\circ} \mathrm{C}$ (assumed based on the study of Basak et al. 2013, and present temperature data). The hot season lasts from March to early June, with daytime temperatures ranging from 38 to $45^{\circ} \mathrm{C}$ across the region (Kramer, 2006). The colonials were culturally and physically unprepared for these temperatures which made their survival much harder. The second climatic challenge was the humidity. The humidity of the Bengal tropical deltaic region is the highest in the whole subcontinent (Kramer, 2006). In turn, higher humidity affects the experience of temperature, which feels higher than the measured temperature. In turn, in the hot humid summer and rainy seasons, the body must continuously sweat. Continuing daily tasks without producing sweat is impossible outdoors, or even in indoor environments during summer and monsoon season. Given the cultural aspects of clothing and work routines, this must have been a highly uncomfortable situation for the British officers. The third contrasting factor for the colonials was the nonstop rainfall during the monsoon season (Kramer, 2006). During monsoon rains building openings have to be kept closed, which raises the room temperature due to the high humidity, heat and lack of air flow. This causes further discomfort and sweating. The monsoonal rains are augmented by heavy downpours 
eTropic 19.2 (2020) Special Issue: Sustainable Tropical Urbanism

and driving rains caused by winds and tropical storms, which likewise challenge the buildings of the delta region (Kramer, 2006).

In summary, there are three major climatic factors that can (and should) inform and direct the architectural characteristics of any building in the Bengal delta, these are: solar radiation and temperature, humidity, and driving rain. The matter under investigation is how these factors challenged colonial buildings in Khulna, and how these buildings responded to these three climatic factors.

\section{The Colonial Enclave in Khulna}

Khulna was established as a sub-divisional centre and colonial city in 1942 (Mridha \& Khan, 2004; Rahaman, 2008). In the Bengal delta colonialism began in Kolkata as it was the first capital of the British East India Company. Geographically Khulna is close to Kolkata and there is no major geographical barrier, such as a large river between them (Figure 2). The extension of the Kolkata-Jessore railway to Khulna in 1885 strengthened the city's connection to the colonial capital, which acted as a powerful driver of the growth of Khulna as a colonial city (Rahaman, 2008). As the importance of the colonial municipality grew, various types of buildings evolved in Khulna, including: administrative, educational, transportation infrastructure, residential facilities for government officials, and privately owned houses (Mridha \& Khan, 2004).

Figure 2. Position of Calcutta, Khulna and Dhaka on the Ganges-Brahmaputra delta floodplains

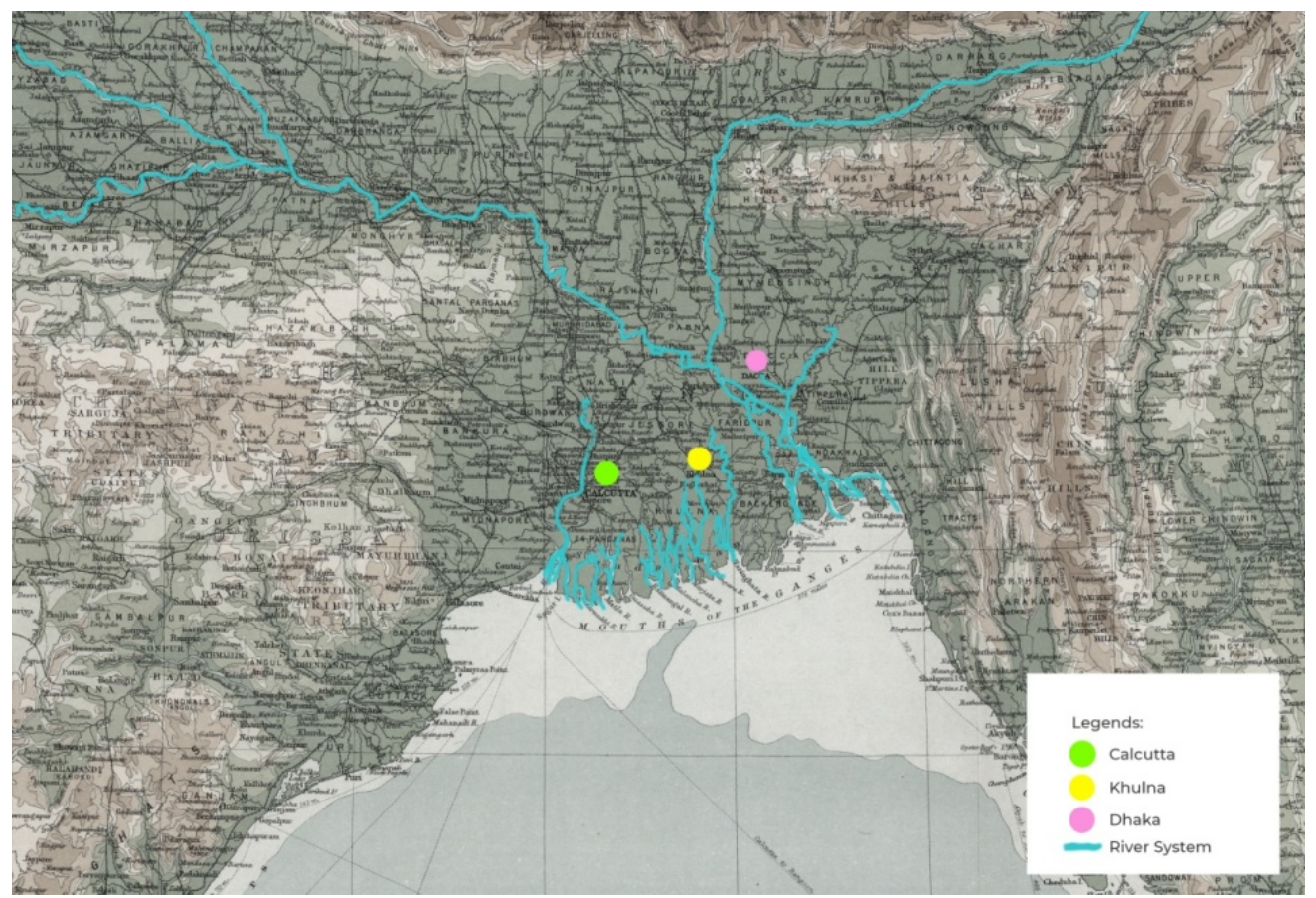

Adapted from John Bartholomew \& Son, The Times Atlas, Edinburgh Geographical Institute, Plate 57 
eTropic 19.2 (2020) Special Issue: Sustainable Tropical Urbanism

Khulna's early colonial buildings took their position parallel to the river around Metal Road (present day K. D. Ghosh Road), and gradually expanded landwards away from the river. At the beginning of the $19^{\text {th }}$ century the whole lower Jessore Road became an administrative zone of the British colony (Mridha \& Khan, 2004). Eventually, emulating the colonial administrative buildings, the local merchants and elite class started to adopt colonial architecture. The Mirzapur area became known as a residential quarter of colonial Khulna (Mridha \& Khan, 2004). Khulna continued to gain higher density and gradually became famous for its colonial urban culture. The colonial enclave was considered aesthetic and neat and this attracted many elites and zamindars to setup their summer resorts in the enclave (Mridha \& Khan, 2004). As a result, many colonial buildings were erected around Gagan Babu Road, Shamsur Rahaman Road, Ahsan Ahmed Road and their surrounds.

Figure 3 Growth map of Khulna, 1925. Figure 4 Satellite map of Khulna, marked colonial enclave

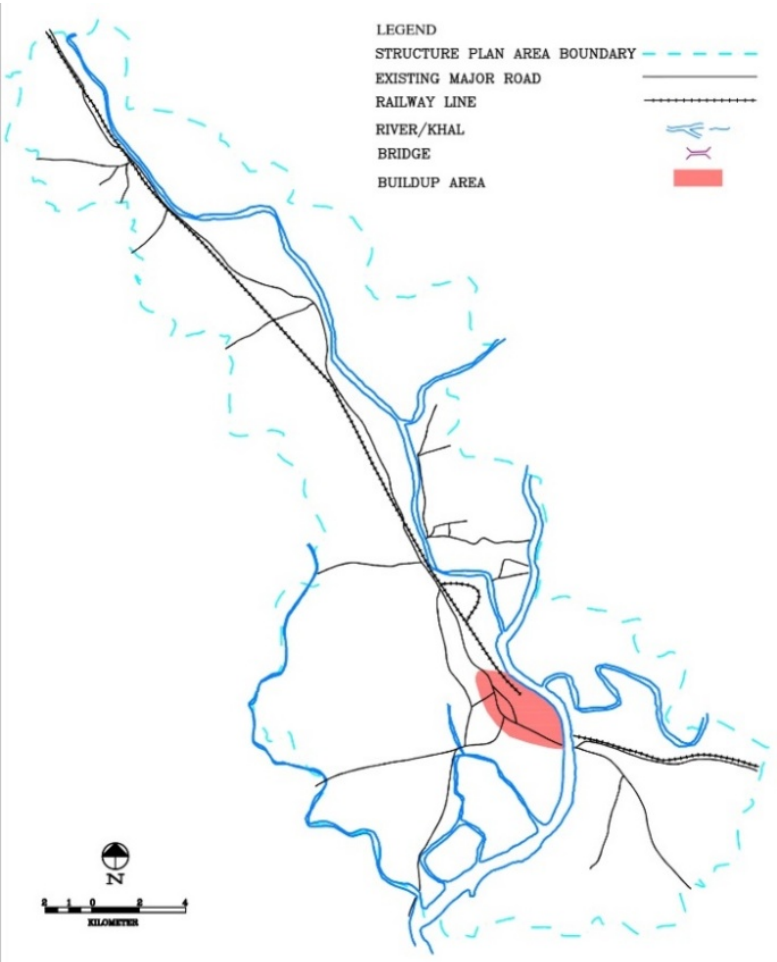

Source: Khulna Development Authority

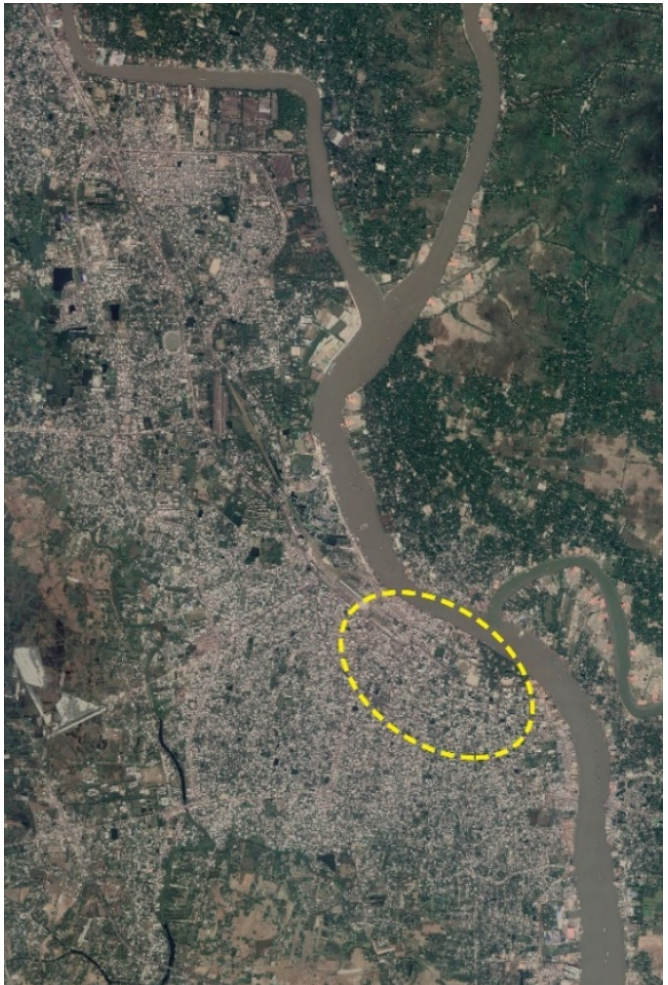

Source: Authors

However, despite its rich colonial establishment and history, presently, Khulna is losing many of its colonial buildings due to neglect and urbanisation. At the beginning of the 21st century, more than 200 potential colonial buildings were identified in the Colonial enclave of Khulna. Yet most of those buildings are now dilapidated (Rahaman, 2008). 
eTropic 19.2 (2020) Special Issue: Sustainable Tropical Urbanism

Furthermore, a large number of the colonial buildings are being demolished under pressure of contemporary urban growth. Most of the buildings are private property and the government does not have a mechanism in place regarding the conservation of these colonial buildings. In today's current conditions of rapid urban growth, economic factors have overpowered heritage and environmental concerns, and Khulna is witnessing the demolition of these old buildings and the development multi-story modern buildings. Within the context of these changes in urbanisation, this study of present buildings is essential in order to extract the architectural and environmental knowledge that is embodied within each colonial heritage building.

\section{Methodology}

To fulfil the objective of this study on how the tropical environment impacted colonial architecture, the background climatic forces of the Bengal deltaic region were outlined. High temperatures caused by direct solar radiation and heavy humidity were the main challenges that created a situation of discomfort for the British colonials (Kramer, 2006). Similarly, the heavy monsoon rain and frequent tropical storms were experienced as unusual. Another unique factor in the delta region were the seasonal variations. From this tropical environment understanding this study further investigates how the colonial buildings have responded to three main factors of (1) temperature, (2) humidity and (3) driving rain.

To study the architectural features which demonstrate environmental adaptation of the buildings an observation framework was contextualized reviewing the previous frameworks of Koenigsberger et al. (1975), Singh et al. (2011), Bodach et al., (2014), Kubota and Toe (2015) and Dili et al., (2010). This framework proposes observing the characteristics of: (1) Building Orientation, (2) Spatial Arrangements, (3) Openings and Windows, (4) Shading Devices, (5) Natural Ventilation Systems and (6) Semi-Open Spaces to identify climatic considerations in architectural projects. A diagram of the study framework is reproduced below in Figure 5 . 
eTropic 19.2 (2020) Special Issue: Sustainable Tropical Urbanism

Figure 5. Framework of the Study

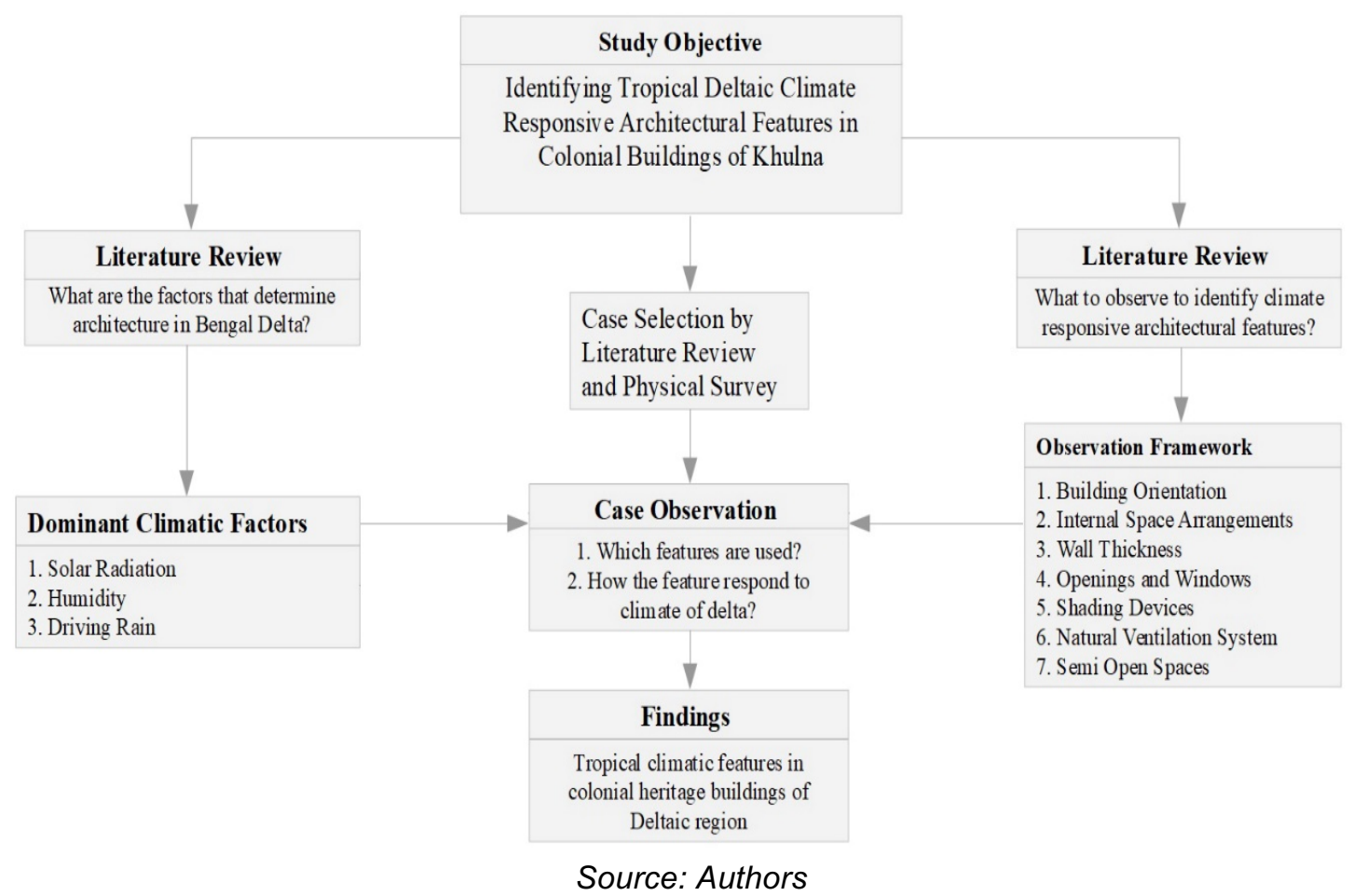

Following our background study of the colonial enclave of Khulna derived from the relevant academic literature, it was necessary to conduct an empirical investigation. For this aspect of the study we undertook a physical survey of the total area of the colonial enclave of Khulna.

The survey identified the existence of more than 50 potential colonial period buildings. These buildings are located on K. D. Ghosh Road, Bhairab Stand Road, Upper Jessore Road, South Central Road, Shamsur Rahman Road, Ahsan Ahmed Road, Gagan Babu Road and their near surrounds. A map identifying these areas can be viewed in Figure 6. 
eTropic 19.2 (2020) Special Issue: Sustainable Tropical Urbanism

Figure 6. Map of identified potential colonial buildings in the colonial enclave of Khulna, 2020.

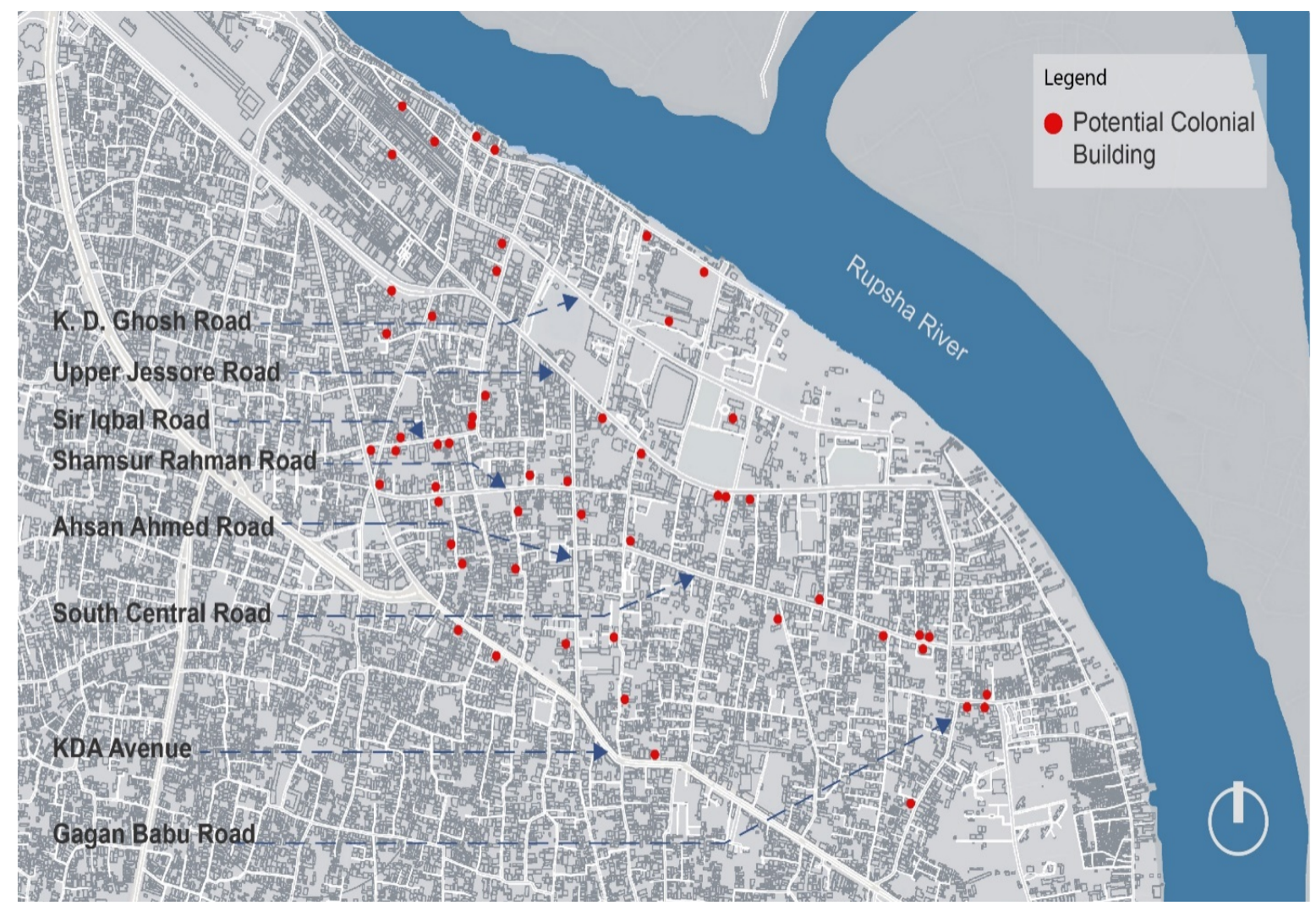

Source: Authors

Among these buildings major portions are worn out and in treacherous condition. Some buildings have been modified by their owners in such a manner as to aesthetically contrast with the features of their colonial identity, and thus depreciate their historical legacy. Only 10 to 15 buildings were found in good condition and clearly showing the features of their colonial identity.

Previously in he Colonial era, all these buildings fell under either of two types of ownership, private sector or government sector. Among the private sector buildings all were used for residential purposes, while the government sector buildings included various uses, such as: residential, administrative, healthcare, and public amenities (Mridha \& Khan, 2004). Even though these buildings served different purposes and uses, they all bear a great similarity in their building forms and features. 
Figure 7. Images of some potential colonial buildings in the colonial enclave of Khulna

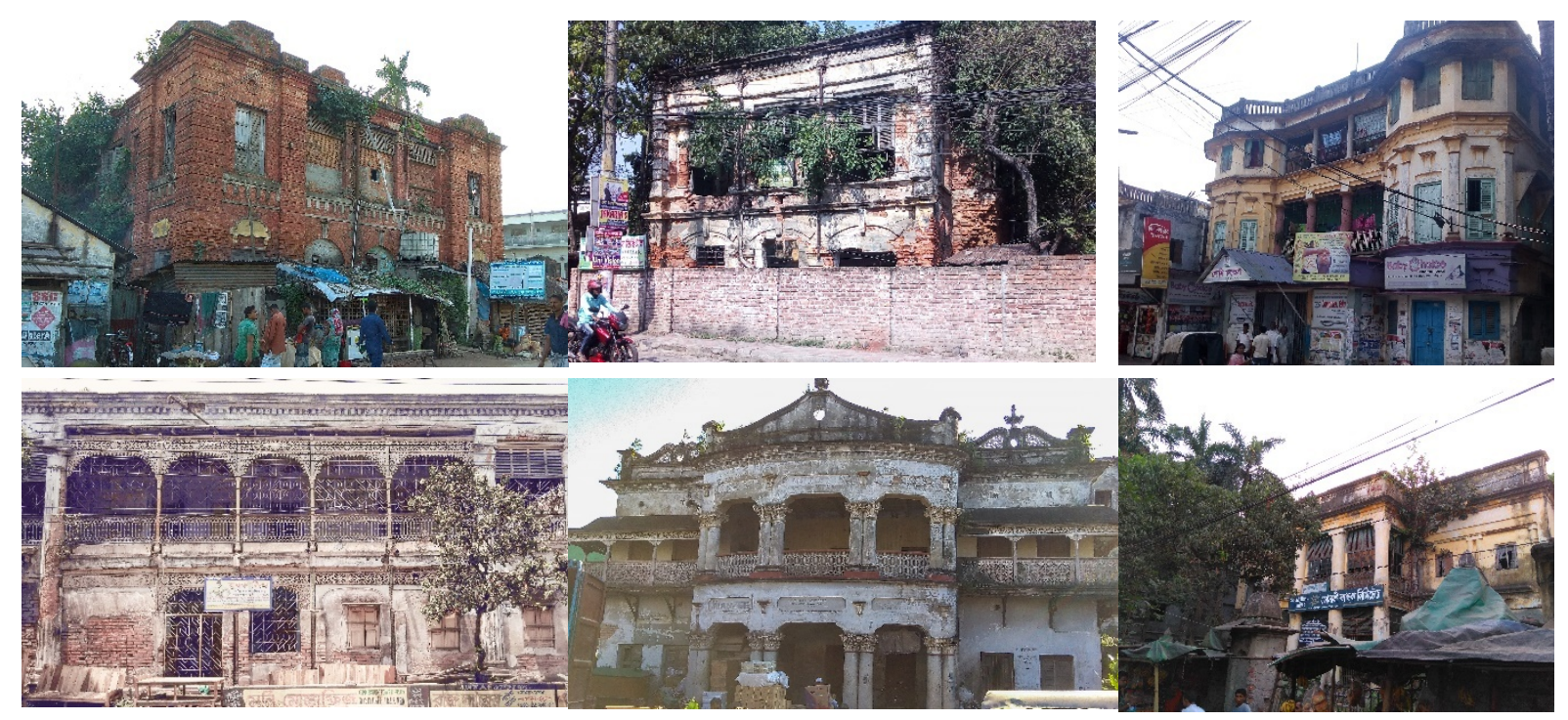

Photographs: Hasan Muntasir, 2019

To carry out the research work in a structured way we had to ascertain the features and conditions of these many buildings in order to select case study buildings for further analysis. Firstly, we identified buildings which are still in good condition. Then we narrowed our search to those buildings which have no modification in their physical form and clearly retain their colonial features. We also considered the construction period of the buildings in order to have a clear perception regarding their colonial features. Under this process we narrowed our investigation to four buildings within the colonial enclave which addressed all the criteria of the selection process. The four case study buildings are coded A, B, C and D. Table 1 presents the tabulated essential locational and use information regarding the four buildings.

Table 1 Description of the selected buildings as case studies

\begin{tabular}{|c|c|c|c|c|c|}
\hline Building & Location & Past use & Present use & $\begin{array}{l}\text { Approximate } \\
\text { building age } \\
\text { in } 2020\end{array}$ & Ownership \\
\hline A & South Central Road, Khulna & Residence & Residence & 180 years old & Private \\
\hline B & $\begin{array}{l}\text { 12, Ahasan Ahmed Road, } \\
\text { Khulna }\end{array}$ & $\begin{array}{l}\text { Office } \\
\text { building }\end{array}$ & $\begin{array}{l}\text { Primary } \\
\text { school }\end{array}$ & 150 years old & Government \\
\hline C & Gagan Babu Road, Khulna & Residence & Residence & 90 years old & Private \\
\hline D & $\begin{array}{l}\text { 18, Shamsur Rahman } \\
\text { Road, Khulna }\end{array}$ & $\begin{array}{l}\text { Residential } \\
\text { hotel \& bar }\end{array}$ & $\begin{array}{l}\text { Mixed-use } \\
\text { building }\end{array}$ & 120 years old & $\begin{array}{l}\text { Formerly } \\
\text { Government; } \\
\text { now private }\end{array}$ \\
\hline
\end{tabular}


Figure 8. The four colonial period buildings selected as cases studies

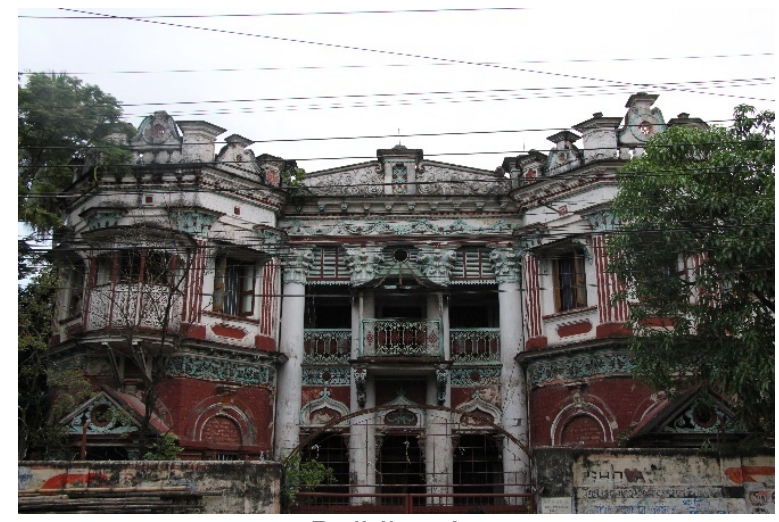

Building A

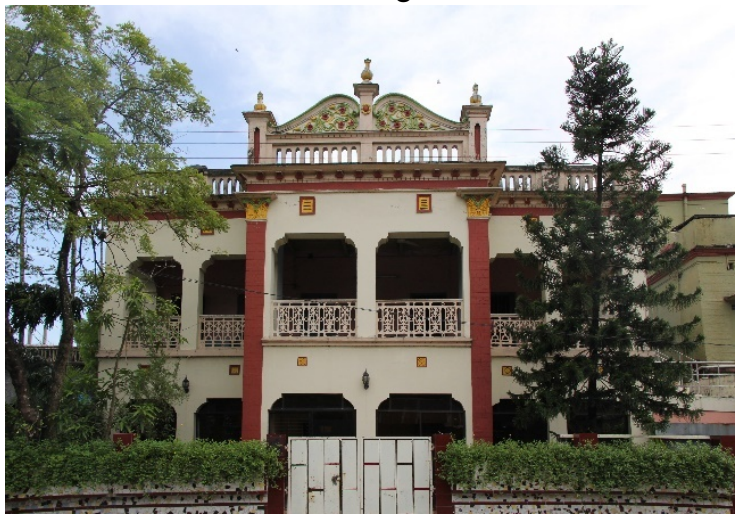

Building C

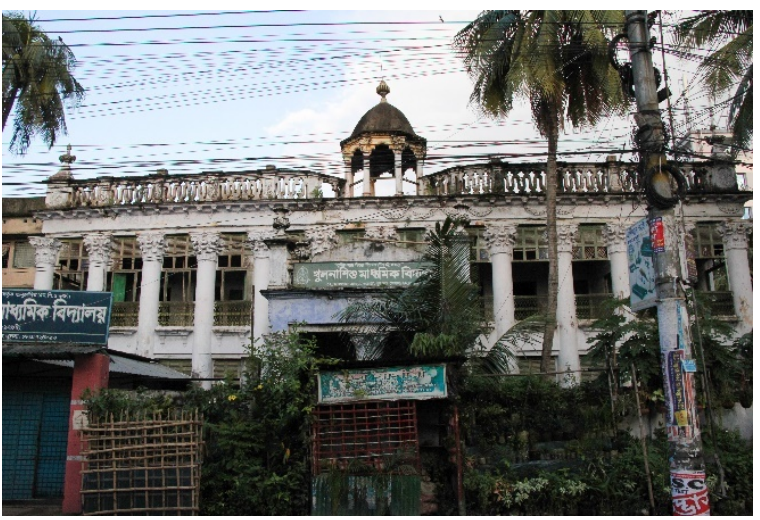

Building B

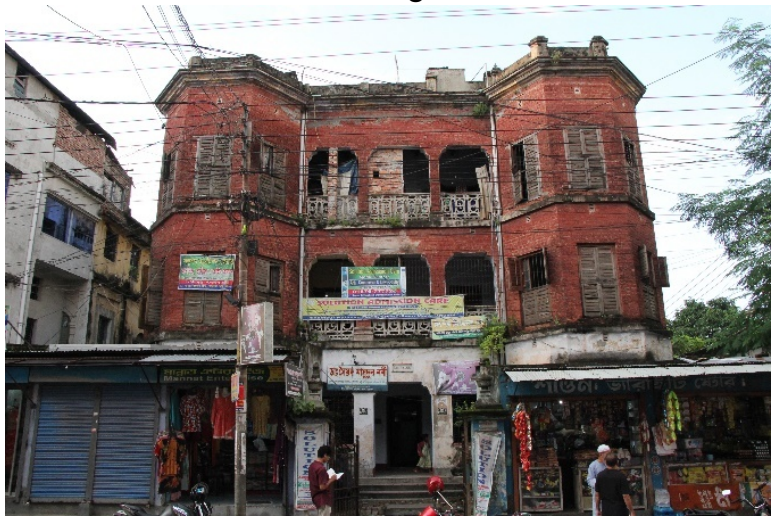

Building D

Photograph: Hasan Muntasir, 2019.

An empirical field survey was undertaken of each of the four buildings, including: photographic data collection, interviews, historical data enquiry, a study of the spatial layout and analysis of identifying features. Schematic plans and sections of selected buildings were also prepared for spatial analysis. This data is analysed with the climatic driving factors and architectural adaptation features previously ascertained from the literature reviews, which helped in the identification of the tropical features of the selected buildings. Lastly, a detailed study of the identified tropical features of the cases has been undertaken.

\section{Design Considerations in Colonial Buildings Responsive to Tropical Climate}

The orientation of buildings $A, C$ and $D$ are north-south facing which means the east and west side has less exposure to climate. This is a significant design consideration in the Bengal deltaic region. The front of buildings $A$ and $C$ is to the north, and the front of Building $D$ is to the south. Each of these three buildings has an 'l' shaped form and they bear similarities in spatial arrangements. These north-south facing and east-west 
elongated buildings are particularly suitable regarding the sun path and prevailing winds of the Khulna region. Service spaces like stairs, toilets and kitchens are placed in the west of the buildings, and in some cases also in the east. In A, C and D buildings, the spatial layout is arranged as such that access to rooms are through a central living space. A continuous buffer space for circulation is designed around the main living space in the form of either a verandah or semi-outdoor gallery.

Figure 9. Plan of building A (not to scale)

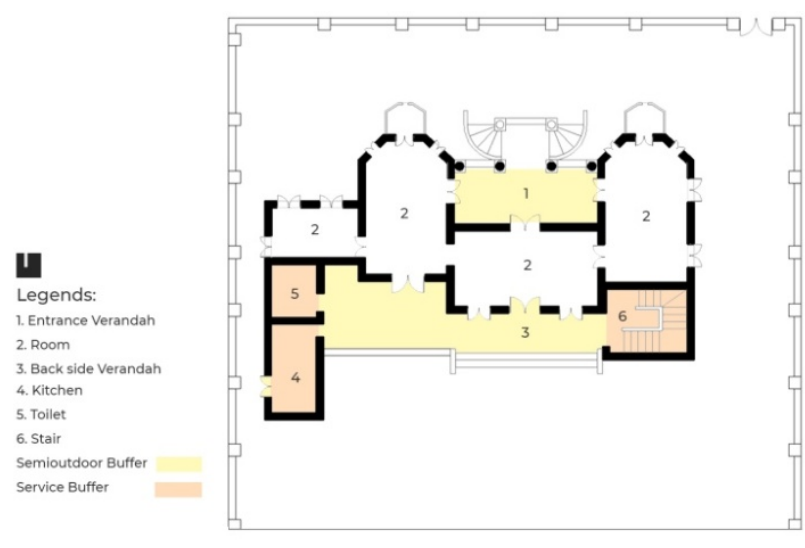

Source: Authors

Figure 11. Plan of building C (not to scale).

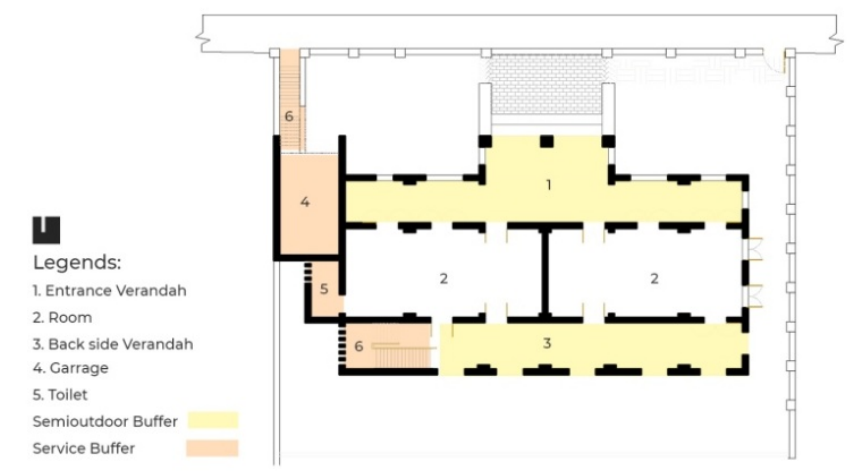

Source: Authors
Figure 10. Building A, frontal space with outdoor and semi-outdoor setting

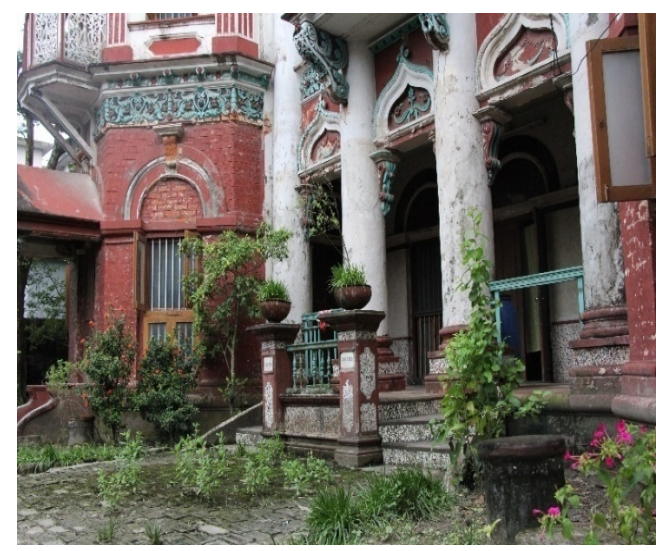

Photograph: Hasan Muntasir, 2019

Figure 12. Semi-outdoor gallery space in the upper level of building $C$

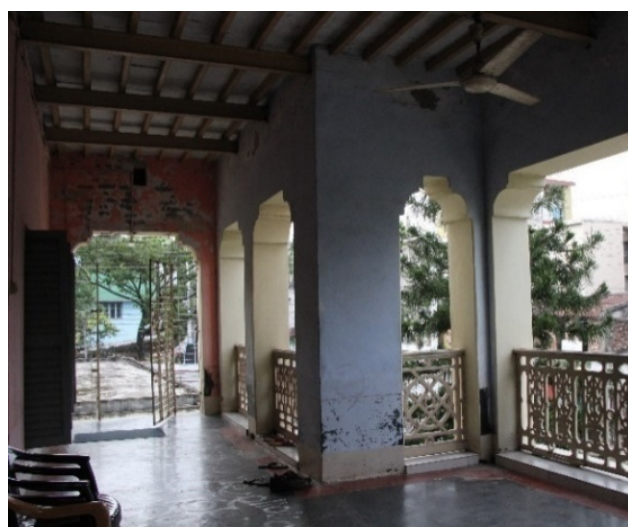

Photograph: Hasan Muntasir, 2019

Building B was formerly an office building, now used as a primary school. It is mainly east-west facing with linear arrangements of rooms along an elongated corridor cum verandah space. The extent of the semi-outdoor gallery is vast in comparison to the building footprint. A service block is attached at the south-east section, making the building 'L' shaped. The rooms are approached through the verandah by a series of doors, and to ensure cross ventilation the opposite façade of the room has large 
windows. The ground floor has semi-outdoor verandah spaces on both west and east sides of the rooms, whereas on the first floor the back verandah is omitted and the rooms are enlarged. A projected porch gives grandeur and an inviting entrance. This building has a very large and strong outdoor setting with two green courts in the southern and eastern sections. A pond is also featured in the eastern court.

Figure 13. Section of building C (not to scale)

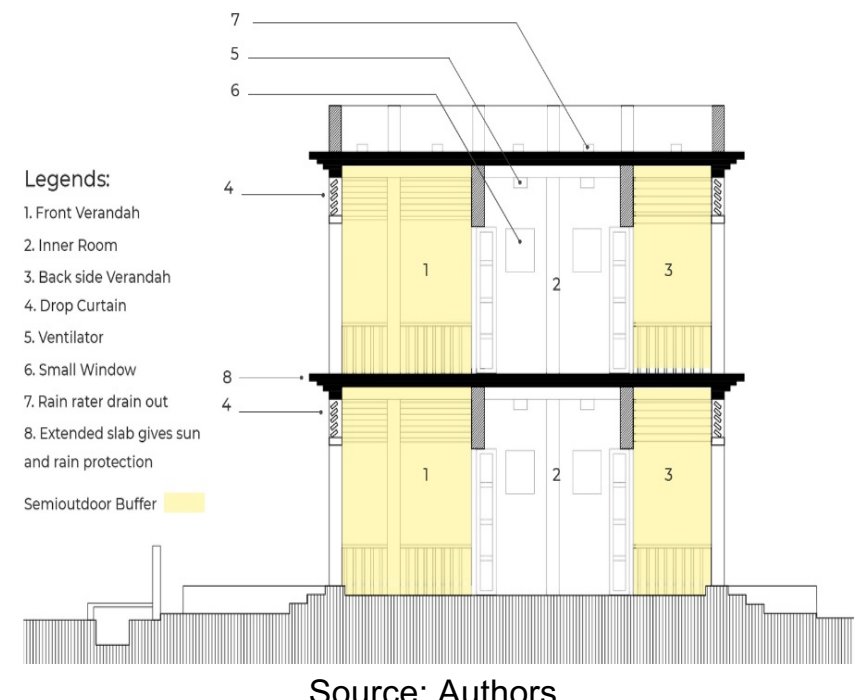

Source: Authors

Figure 15. Conceptual plan of building B

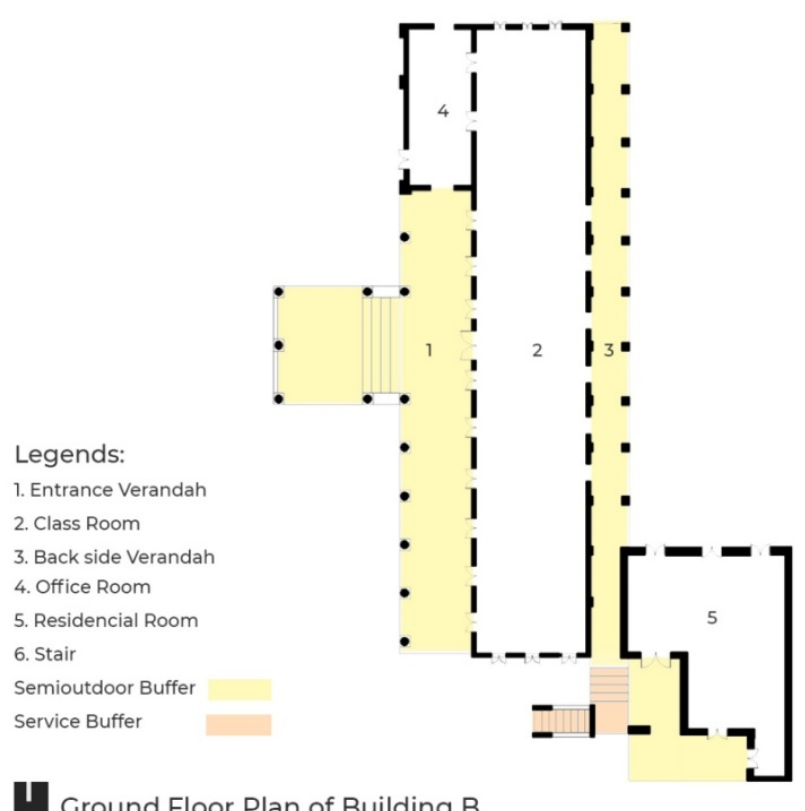

Source: Authors
Figure 14. Plan of building $D$ (not to scale)

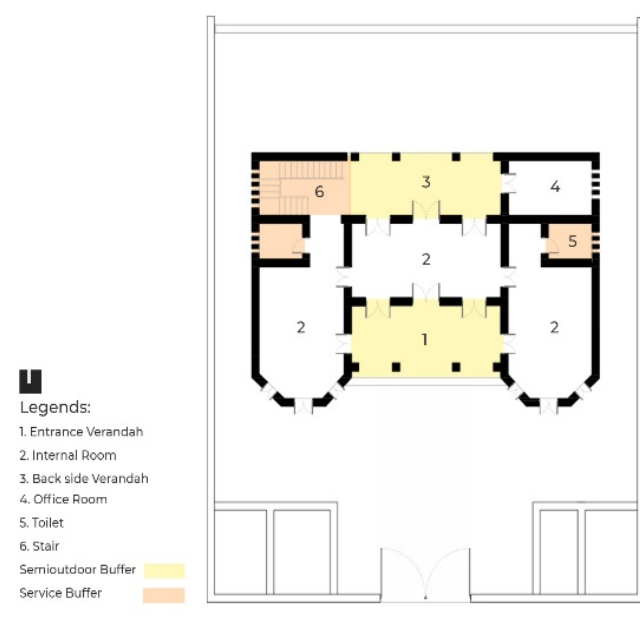

Source: Authors

Figure 16. Building $B$ with southern green court

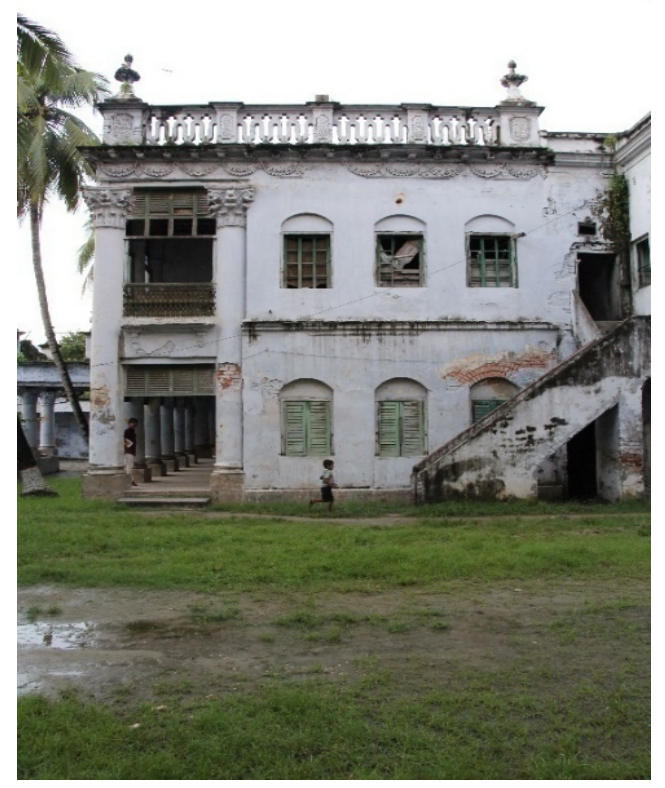

Photograph: Hasan Muntasir, 2019. 
eTropic 19.2 (2020) Special Issue: Sustainable Tropical Urbanism

\section{Featured Architectural Components}

\section{Drop Curtains}

Drop curtains are observed as horizontal louvre panels in Buildings A and B. These louvre panels are made of wood with a separate linear wooden band attached at the bottom for dripping rain water (Figures 10,11). Drop curtains made of solid filled stucco or perforated Jali stucco are observed in Buildings $C$ and $D$ where some drop curtains are incorporated within semi-circular arches in these buildings. All drop curtains are measured at approximately one third of the clear height of the buildings. In some cases, drop curtain panels are subdivided with perforated or solid filled panels (Figures 10, 12). As an architectural element incorporated into the elevation of the surveyed buildings, these drop curtains mainly prevent driving rain while allowing for free air flow and natural ventilation within the building interior. These ornamental additions on the building envelope also work efficiently as shading devices to cut the glare of summer sun in the tropical climate context of Khulna.

\section{Eaves and Brackets}

Brackets were observed overhanged at certain intervals from the horizontal band of eaves. These brackets contained intricate ornamentations. All four surveyed buildings had similar kinds of eaves, however brackets were present only in Buildings A, B and $C$. The primary function of the eaves is to keep rain water away from the walls and to prevent the ingress of water at the junction of roof and wall in order to reduce damping effects on the building. The eaves also act to protect the immediate offset-space of the ground around the building from rain, prevent erosion of the footings, and reduce splatter on the outside walls from rain as it hits the ground. The secondary function of the eaves is to control solar penetration as a form of passive solar building design. The eaves overhang is designed to reduce the building's solar gain in accordance with the tropical climate, the latitude, and the orientation of the building. The eaves' overhang also shelters the openings that ventilate the ceiling space.

\section{Ventilators}

Ventilators in more-or-less square or rectangular shapes were apparent in all four of the surveyed buildings. The ventilators were made of stucco or perforated metal and ornamented with designs or simple horizontal bands. In the surveyed buildings ventilators were observed at every elevation, but were mostly visible on the northsouth façade. Ventilators were placed along the vertical references of windows or 
openings. Although they are small in size, they are numerous, which acts to multiple their effect. They are used to create a stack effect which draws hot air from the interior of the building to the outside.

\section{Windows}

All four surveyed buildings have similarities in their design and use of windows. Windows are installed at a certain depth inside the wall surface instead of being flush with the wall elevation. In Buildings $A$ and $B$ arches are provided on certain windows to provide shade. Use of jalousie windows with operable louvres are observed in all four buildings. Some windows are subdivided into two parts, while the use of swing windows is also observed in some cases for ensuring highest aperture. Sunshades are noticed over the windows and most of the windows start from floor level and are divided into two parts. Windows have vertical wooden or metal grills. Use of glass is observed in the windows of Building $A$ and simple glass panel is used in some windows in the inner layer of Building D. Most windows start from the floor level and have a height of two-thirds of the floor height.

Figure 17. Louvred drop curtain in upper level and solid drop curtain lower level of building $A$

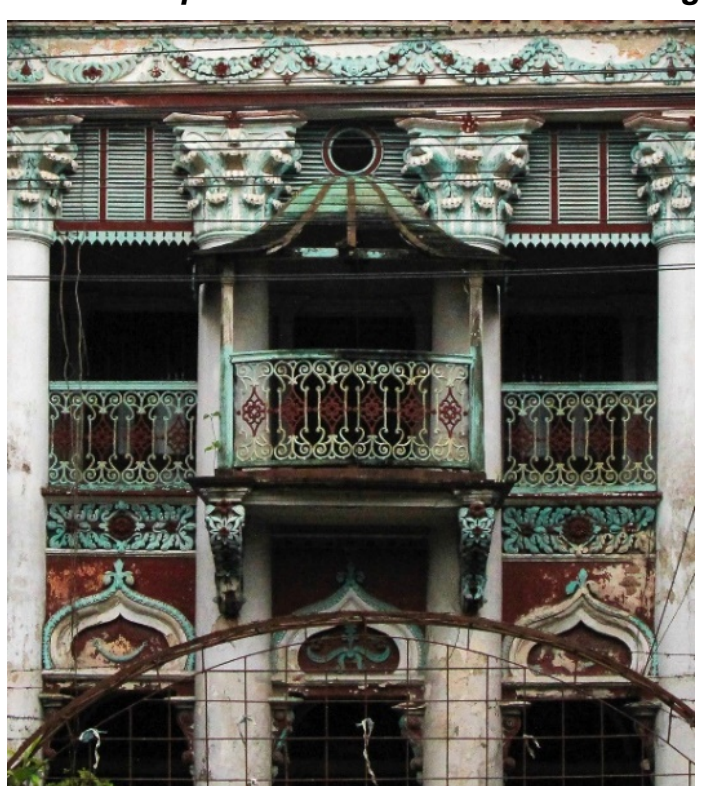

Figure 18. Louvred drop curtain in lower level of building $B$

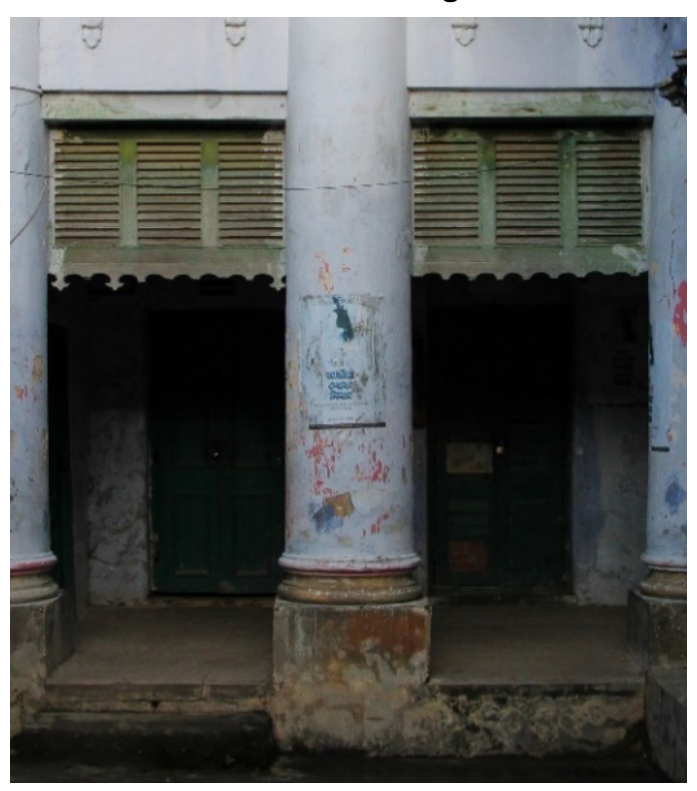

Photographs: Hasan Muntasir, 2019 
eTropic 19.2 (2020) Special Issue: Sustainable Tropical Urbanism

Figure 19. Perforated drop curtain with arch in building $A$.

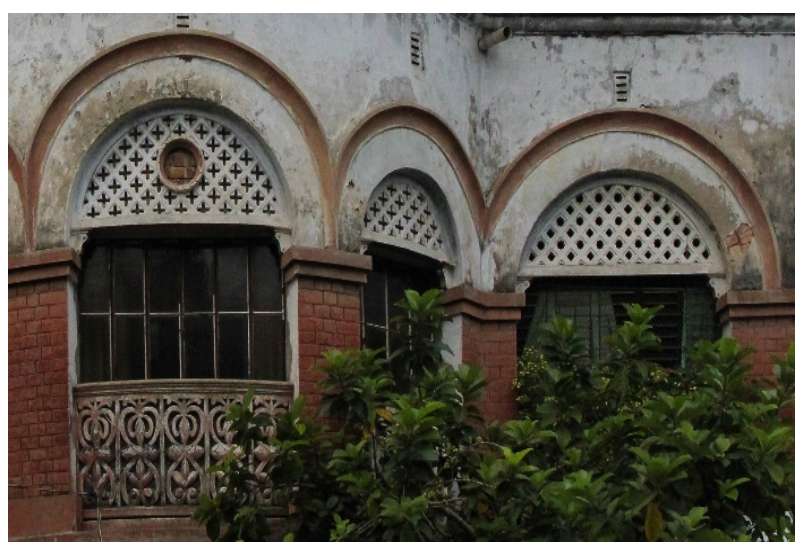

Figure 21. Eaves and brackets of building C

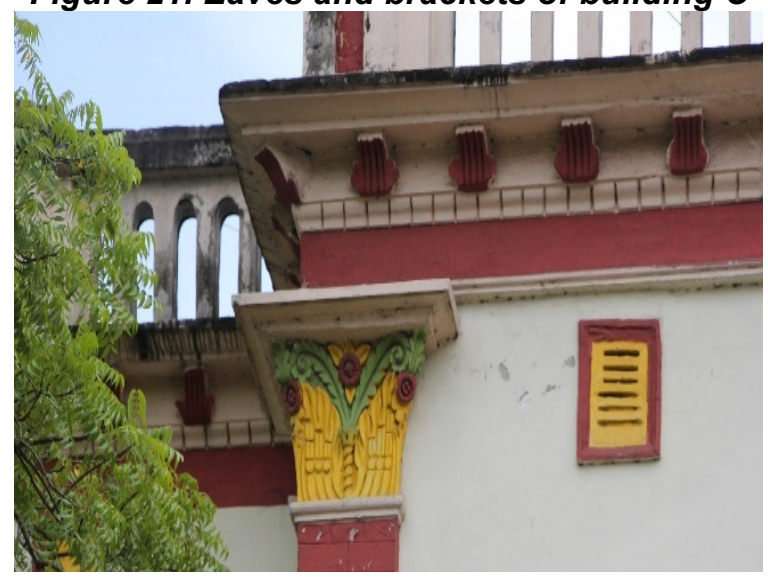

Figure 23. Series of ventilators in building B

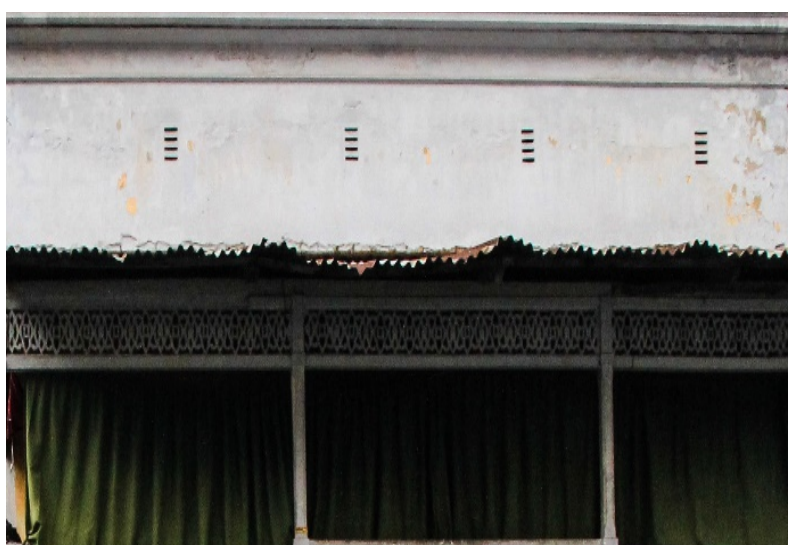

Photographs: Hasan Muntasir, 2019
Figure 20. Multiple rows of louvred drop curtain in the upper level of building $B$.
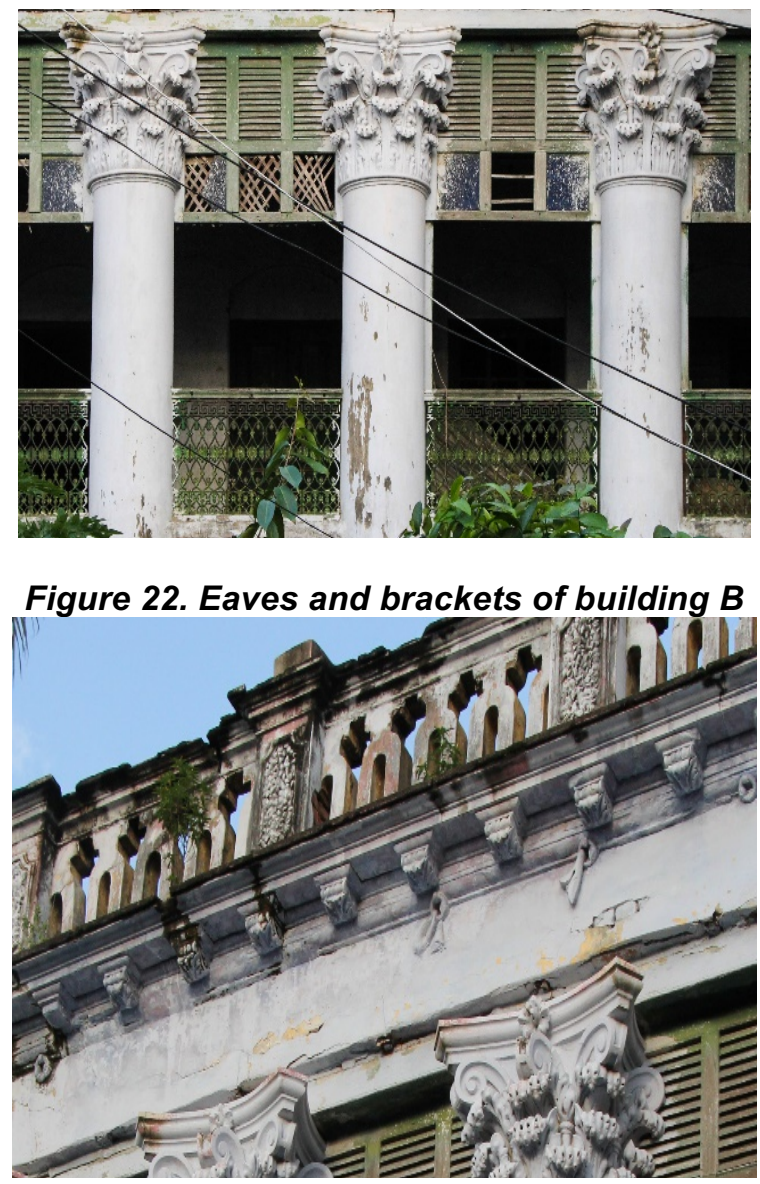

Figure 24. Ornamental ventilators building C

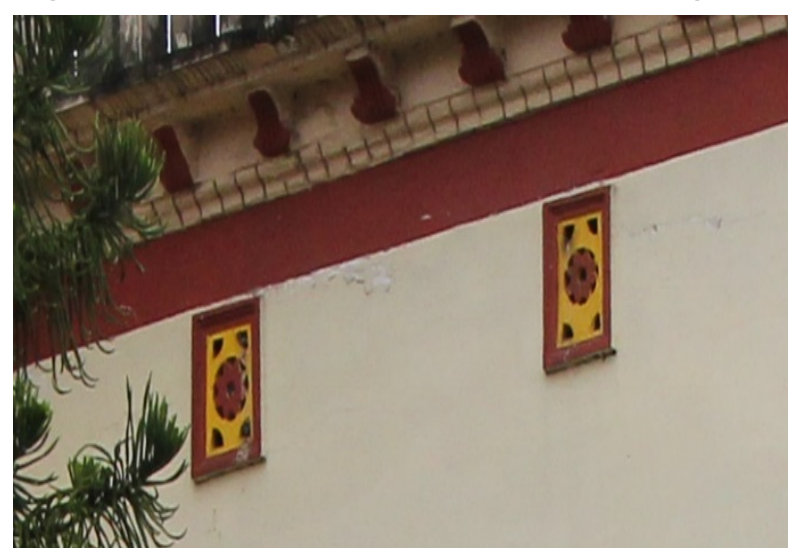


eTropic 19.2 (2020) Special Issue: Sustainable Tropical Urbanism

Figure 25. Use of jalousie shutters, building C

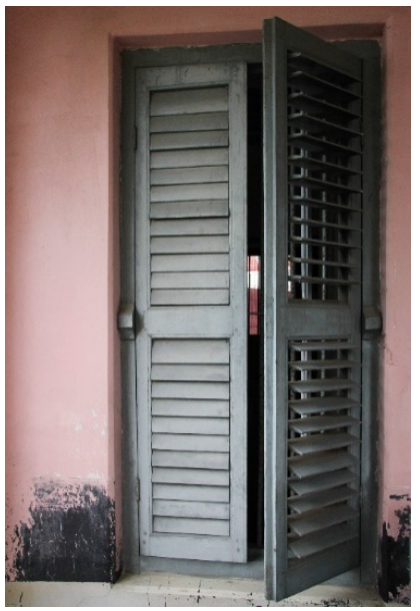

Figure 27. Windows are subdivided into two parts in building $A$

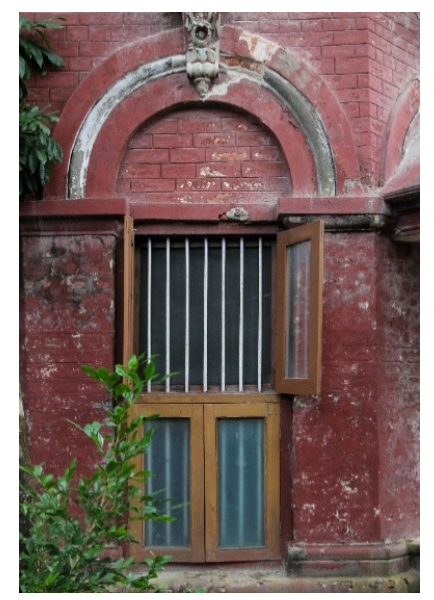

Figure 26. Window overhang, building $A$

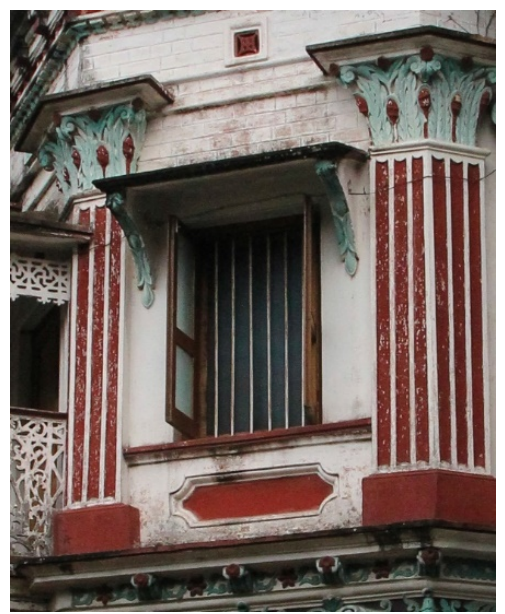

Figure 28. Windows are installed at a certain depth inside the wall surface in building $B$

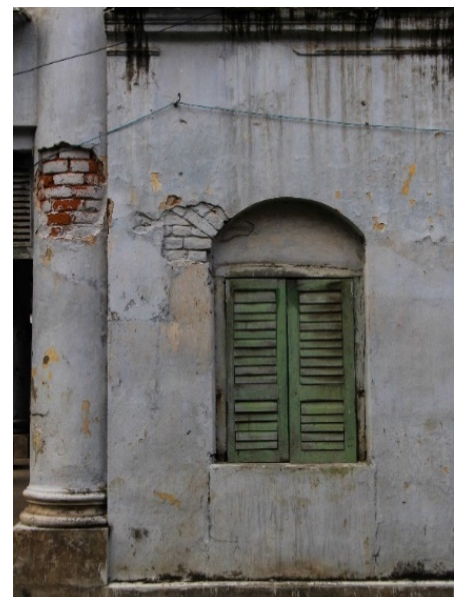

Figure 31. Window starting at floor level, two-thirds of floor height, building $D$

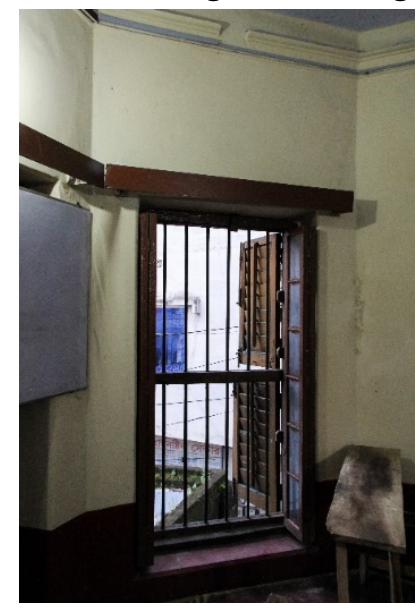

Figure 29. Use of simple glass panel window in inner layer of north-side in building $D$

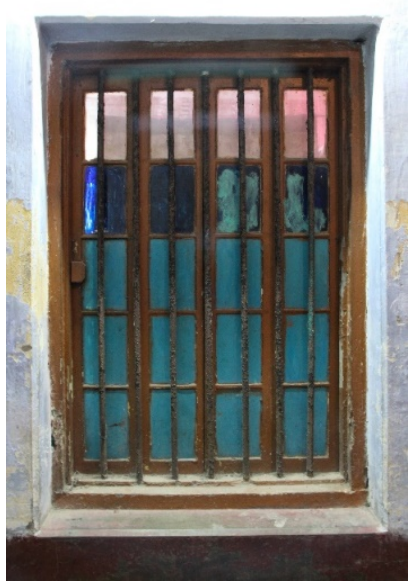

Figure 30. Use of jalousie and windows subdivided into two parts, inner layer of building $D$

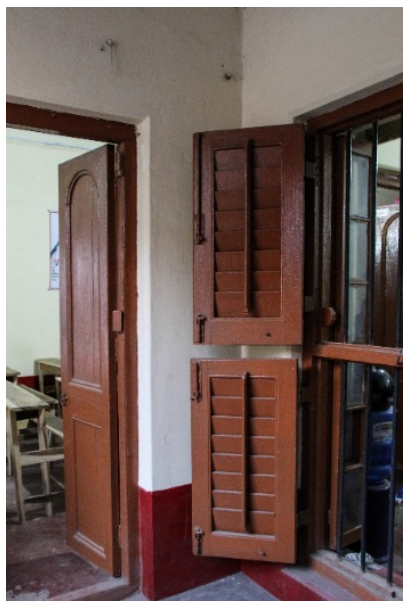

Photographs: Hasan Muntasir, 2019 
eTropic 19.2 (2020) Special Issue: Sustainable Tropical Urbanism

Table 2. Design considerations responsive to tropical climate in four selected buildings

\begin{tabular}{|c|c|c|c|c|c|}
\hline & Building A & Building B & Building C & Building D & $\begin{array}{l}\text { Climatic } \\
\text { Considerations }\end{array}$ \\
\hline $\begin{array}{l}\text { Building } \\
\text { orientation }\end{array}$ & $\begin{array}{l}\text { North-South facing } \\
\text { Front face North }\end{array}$ & $\begin{array}{l}\text { East-West } \\
\text { Facing } \\
\text { Front face West }\end{array}$ & $\begin{array}{l}\text { North-South } \\
\text { facing } \\
\text { Front face North }\end{array}$ & $\begin{array}{l}\text { North-South } \\
\text { Facing } \\
\text { Front face South }\end{array}$ & $\begin{array}{l}\text { Minimize solar heat } \\
\text { gain, } \\
\text { Maximize exposure } \\
\text { to southern wind in } \\
\text { hot seasons }\end{array}$ \\
\hline $\begin{array}{l}\text { Spatial } \\
\text { arrangement }\end{array}$ & $\begin{array}{l}\text { Semi outdoor buffer } \\
\text { in north and south, } \\
\text { Service buffer in } \\
\text { east and west }\end{array}$ & $\begin{array}{l}\text { Semi outdoor } \\
\text { buffer in west } \\
\text { A service block } \\
\text { is attached at the } \\
\text { south-east part }\end{array}$ & $\begin{array}{l}\text { Semi outdoor } \\
\text { buffer in north and } \\
\text { south, } \\
\text { Service buffer in } \\
\text { west }\end{array}$ & $\begin{array}{l}\text { Semi outdoor } \\
\text { buffer in north } \\
\text { and south, } \\
\text { Services are } \\
\text { placed in north- } \\
\text { east and north- } \\
\text { west }\end{array}$ & $\begin{array}{l}\text { Semi outdoor and } \\
\text { service buffers } \\
\text { protect inner living } \\
\text { spaces from solar } \\
\text { radiation and rain }\end{array}$ \\
\hline $\begin{array}{l}\text { Semi-open } \\
\text { spaces }\end{array}$ & $\begin{array}{l}\text { Front verandah at } \\
\text { north, } \\
\text { Back verandah at } \\
\text { south which is } \\
\text { larger }\end{array}$ & $\begin{array}{l}\text { Wider front } \\
\text { verandah facing } \\
\text { west, Entrance } \\
\text { porch at west, } \\
\text { Narrow back } \\
\text { verandah at east }\end{array}$ & $\begin{array}{l}\text { Front verandah at } \\
\text { north, } \\
\text { Back verandah at } \\
\text { south which are } \\
\text { almost equal }\end{array}$ & $\begin{array}{l}\text { Front verandah } \\
\text { at south which is } \\
\text { about } 10^{\prime} \text { deep, } \\
\text { Back verandah } \\
\text { at north a little } \\
\text { less in depth but } \\
\text { equal in length }\end{array}$ & $\begin{array}{l}\text { Verandah at north } \\
\text { and south protects } \\
\text { inner spaces from } \\
\text { direct solar } \\
\text { exposure and } \\
\text { driving rain in } \\
\text { summer monsoon, } \\
\text { Southern verandah } \\
\text { gets comfortable } \\
\text { sunlight in winter }\end{array}$ \\
\hline $\begin{array}{l}\text { Ventilation } \\
\text { Systems }\end{array}$ & $\begin{array}{l}\text { Cross ventilation } \\
\text { through north south } \\
\text { windows, } \\
\text { Stack effect } \\
\text { ventilation through } \\
\text { upper level square } \\
\text { shaped } \\
\text { ornamented } \\
\text { ventilators }\end{array}$ & $\begin{array}{l}\text { Cross ventilation } \\
\text { through east } \\
\text { west windows, } \\
\text { Stack effect } \\
\text { ventilation } \\
\text { through upper } \\
\text { level ventilators }\end{array}$ & $\begin{array}{l}\text { Cross ventilation } \\
\text { through north } \\
\text { south windows, } \\
\text { Stack effect } \\
\text { ventilation through } \\
\text { upper level } \\
\text { ventilators }\end{array}$ & $\begin{array}{l}\text { Cross ventilation } \\
\text { through north } \\
\text { south windows, } \\
\text { Stack effect } \\
\text { ventilation } \\
\text { through upper } \\
\text { level ventilators }\end{array}$ & $\begin{array}{l}\text { Cross ventilation } \\
\text { reduces discomfort } \\
\text { of higher humidity, } \\
\text { Stack effect } \\
\text { ensures cross } \\
\text { ventilation even if } \\
\text { doors and windows } \\
\text { are closed ie. at } \\
\text { night or during rain }\end{array}$ \\
\hline Wall thickness & $\begin{array}{l}\text { All outer and most } \\
\text { inner walls are } 20 \\
\text { inch thick made of } \\
\text { brick }\end{array}$ & $\begin{array}{l}\text { All outer and } \\
\text { most inner walls } \\
\text { are } 20 \text { inch thick } \\
\text { made of brick }\end{array}$ & $\begin{array}{l}\text { All outer and most } \\
\text { inner walls are } 20 \\
\text { inch thick made of } \\
\text { brick }\end{array}$ & $\begin{array}{l}\text { All outer and } \\
\text { most inner walls } \\
\text { are } 20 \text { inch thick } \\
\text { made of brick }\end{array}$ & $\begin{array}{l}\text { Protects from solar } \\
\text { radiation, } \\
\text { Keeps inner space } \\
\text { cold in summer and } \\
\text { warm in winter }\end{array}$ \\
\hline $\begin{array}{l}\text { Shading } \\
\text { Devices }\end{array}$ & $\begin{array}{l}\text { Wooden horizontal } \\
\text { louver panel drop } \\
\text { curtains in north } \\
\text { and south, } \\
\text { Perforated stucco } \\
\text { 'Jali' with semi- } \\
\text { circular arch in } \\
\text { north and south, } \\
\text { Eaves and brackets }\end{array}$ & $\begin{array}{l}\text { Wooden } \\
\text { horizontal louver } \\
\text { panel drop } \\
\text { curtains in west, }\end{array}$ & $\begin{array}{l}\text { Solid filled stucco } \\
\text { in drop curtain in } \\
\text { north and south, }\end{array}$ & $\begin{array}{l}\text { Solid filled } \\
\text { stucco in drop } \\
\text { curtain in south, }\end{array}$ & $\begin{array}{l}\text { Protection from } \\
\text { driving rain, } \\
\text { Protection from } \\
\text { direct solar } \\
\text { radiation, } \\
\text { Perforated to aid } \\
\text { ventilation }\end{array}$ \\
\hline $\begin{array}{l}\text { Windows and } \\
\text { openings }\end{array}$ & $\begin{array}{l}\text { Glass panelled } \\
\text { double-swing } \\
\text { window } \\
\text { At ground floor start } \\
\text { from the floor level } \\
\text { to a height of two- } \\
\text { thirds of the floor } \\
\text { height, on first floor } \\
\text { maintain a seal } \\
\text { from the floor and } \\
\text { have a height half } \\
\text { of the floor height } \\
\text { Arches are } \\
\text { provided on certain } \\
\text { windows } \\
\text { Some are vertically } \\
\text { subdivided into two } \\
\text { parts }\end{array}$ & $\begin{array}{l}\text { Double-swing } \\
\text { jalousie window } \\
\\
\text { Maintain a seal } \\
\text { from the floor } \\
\text { and have a } \\
\text { height half of the } \\
\text { floor height }\end{array}$ & $\begin{array}{l}\text { Double-swing } \\
\text { jalousie window } \\
\text { Start from the } \\
\text { floor level and } \\
\text { have a height of } \\
\text { two-third of the } \\
\text { floor height }\end{array}$ & $\begin{array}{l}\text { Double-swing } \\
\text { jalousie window } \\
\text { and glass } \\
\text { panelled window } \\
\text { both } \\
\text { Start from the } \\
\text { floor level and } \\
\text { have a height of } \\
\text { two-third of the } \\
\text { floor height }\end{array}$ & $\begin{array}{l}\text { Maximum windows } \\
\text { in north and south, } \\
\text { Operable wooden } \\
\text { panels to ensure } \\
\text { ventilation when } \\
\text { closed }\end{array}$ \\
\hline
\end{tabular}


eTropic 19.2 (2020) Special Issue: Sustainable Tropical Urbanism

\section{Conclusion}

To date the majority of Colonial buildings in the Bengal delta have been evaluated at over 100 years old. These buildings are declining at a rapid rate. In Khulna most of the buildings documented by Mridha and Khan (2004) have since been demolished. There is no sign of the prestigious Dak-Bungalow building that Rahaman (2008) previously digitally documented. Most of the colonial buildings in Khulna are situated in the densest part of the city as the historic colonial enclave has continued to be a centre of urban growth. As a result of this growth, land prices are higher in these areas and pressures for development are intense. Multi-story developments in particular are replacing most of the colonial buildings of Khulna. Compounding this issue is that most colonial buildings are privately owned residential buildings, thus government heritage or archaeological departments face difficulties in trying to conserve them. With the demolition of these buildings, the knowledge and innovations behind hybrid colonial architecture design practices also become erased.

Analysing four cases, this study documented that the orientation of the buildings, the spatial arrangements according to the surrounding context and climatic situations, the detail design decisions of the doors, windows and even decorations, all respond to the tropical climate of the Bengal delta. A deep intermediate transitional space between the indoors and outdoors, which is more like a pavilion rather a room and contextually known as a verandah, is a major feature in this tropical context. This semi outdoor pavilion-like buffer zone covers the larger surfaces of all the four buildings. For cross ventilation, most living zones contain windows on the east north and south facades. Moreover, small ventilators at upper levels of the rooms create a stack effect to ensure ventilation even when all doors and windows are closed. The 20 -inch thick brick walls work as thermal insulators in these buildings. In addition to these features, shading devices are used to protect the inner spaces from the tropical solar glare and at the same time act as a ventilation system through incorporating perforations. Doors and windows are designed with operable horizontal louvres giving priority to the ventilation system. The climatic merits of these colonial buildings can enlighten us in a new way. There is a contemporary resurgence in the exploration and practice of tropical architecture. If these Colonial buildings are demolished, the roots of the buildings' tropical ideology may remain undocumented. This study aims to contribute to the growing field of tropical architecture by re-exploring the practices colonial roots from which, according to many researchers, the idea originated.

In the recent 10 to 15-year period many new buildings have evolved in Khulna. Some have tried to regenerate the colonial spirit. But most of them have neither touched the soul, nor the ideology of colonial past. Examples include the City Corporation Building 
eTropic 19.2 (2020) Special Issue: Sustainable Tropical Urbanism

(presently known as Nagar Bhaban Khulna), the new High Court building, and the most depressing example among them, the new railway station building. Without deep understanding of the climate sensitivity of the colonial approach these neo-colonial style buildings have merely blindly imitated colonial façades and columns.

In the face of many current shallow approaches to architecture instigated by rapid urbanisation in the tropics, this study argues for a deep architectural approach and investigates examples of Colonial architectural features that contribute to this field of practice. The climate responsive design considerations adopted by colonial architects under tropical conditions have been re-explored. In the contemporary era of climate change - which has multiple specialised impacts on the tropical regions of the world - the challenges for today's architects have been raised. Investigating and understanding the importance of buildings façades, spatial organization, orientation, openings and further climate protective devices from a climate sensitive approach can add a new dimension for innovation in contemporary architectural practice. A deep understanding and response to major climatic challenges of the Bengal delta temperature, solar radiation, humidity and driving rain - is not only environmentally necessary, but can also act to sustain the identity of deltaic architecture. 
eTropic 19.2 (2020) Special Issue: Sustainable Tropical Urbanism

\section{References}

Adnan, E.R. \& Islam, T. (2018). Late colonial period merchant houses at Birulia: A study on architectural features. In Samarawickrama, S. et al. (Eds.) Proceedings of the 11th International Conference of Faculty of Architecture Research Unit (pp. 316-324). Galle, Sri Lanka: University of Moratuwa.

Afzal, F. (2018). British Colonial Architecture in Bengal. Retrieved from https://www.thedailystar.net/in-focus/british-colonial-architecture-bengal-1536610

Antaryama, I.G.N., Ekasiwi, S.N.N., Mappajaya, A., \& Ulum, M.S. (2018, March). Thermally adapted design strategy of colonial houses in Surabaya. In IOP ConfSer: Earth Environ Sci 126, 1-8. https://doi.org/10.1088/1755-1315/126/1/012048

Atkinson, F. (1969). The genesis of modern tropical architecture. Journal of the Royal Society of Arts, 117(5156), 546-561. http://www.jstor.org/stable/41370384

Atkinson, G. A. (1953). An introduction to tropical building design. Architectural Design, 23(Oct), 268.

Bodach, S., Lang, W., \& Hamhaber, J. (2014). Climate responsive building design strategies of vernacular architecture in Nepal. Energy and Buildings, 81, 227-242. https://doi.org/10.1016/j.enbuild.2014.06.022

Basak, J. K., Titumir, R. A. M., \& Dey, N. C. (2013). Climate change in Bangladesh: a historical analysis of temperature and rainfall data. Journal of Environment, 2(2), 4146.

Chang, J. H. (2016). A genealogy of tropical architecture: Colonial networks, nature and technoscience. Routledge. https://doi.org/10.4324/9781315712680

Chang, J. H., \& King, A. D. (2011). Towards a genealogy of tropical architecture: Historical fragments of power-knowledge, built environment and climate in the British colonial territories. Singapore Journal of Tropical Geography, 32(3), 283-300. https://doi.org/10.1111/j.1467-9493.2011.00434.x

Chee, L., Chang, J. H., \& Wong, B. C. (2011). Introduction-'Tropicality-in-motion': Situating tropical architecture. Singapore Journal of Tropical Geography, 32(3), 277-282. https://doi.org/10.1111/j.1467-9493.2011.00433.x

Ching, F. D., Jarzombek, M. M., \& Prakash, V. (2017). A global history of architecture. John Wiley \& Sons.

Dili, A. S., Naseer, M. A., \& Varghese, T. Z. (2010). Passive environment control system of Kerala vernacular residential architecture for a comfortable indoor environment: A qualitative and quantitative analyses. Energy and Buildings, 42(6), 917-927. https://doi.org/10.1016/j.enbuild.2010.01.002

Doza, S. B. \& Ema, E. A. K. (2019). 'Architecture is Endless'- in the Changing Landscape of the Delta. In Conference Proceedings of Archasia, Dhaka.

Fatemi, N. M., \& Islam, N. (2011). Sustainability and Eco-Adaptibility in Vernacular Housing in Bangladesh. International Conference on Society, Technology \& Sustainable Development. Kochi, India.

Hildegardis, C., Saraswati, A. A. A. O., \& Dewi, N. K. A. (2019). Review of Thermal Comfort in Warm Humid Climate for Traditional Architecture in Indonesia. KnE Social Sciences, 151-167. https://doi.org/10.18502/kss.v3i21.4965

Jackson, I. (2013). Tropical architecture and the West Indies: from military advances and tropical medicine, to Robert Gardner-Medwin and the networks of tropical modernism. The Journal of Architecture, 18 (2), 167-195. https://doi.org/10.1080/13602365.2013.781202

Koenigsberger, O. H., Ingersoll, O.H. \& Mayhew, T.G. (1975). Manual of tropical housing \& building. Orient Blackswan. 
eTropic 19.2 (2020) Special Issue: Sustainable Tropical Urbanism

Kramer, K. (2006). Applying the Lessons of Indian Vernacular Architecture: The Bungalow as Example of Adaptive Climatic Response. The 23rd Conference on Passive and Low Energy Architecture, (6-8 September). Geneva, Switzerland

Kubota, T., \& Toe, D. H. C. (2015). Application of passive cooling techniques in vernacular houses to modern urban houses: A case study of Malaysia. Procedia-Social and Behavioral Sciences, 179, 29-39. https://doi.org/10.1016/j.sbspro.2015.02.408

Lundberg, A. (2008). Material Poetics of a Malay House. TAJA The Australian Journal of Anthropology, 19 (1), 1-16. https://doi.org/10.1111/j.1835-9310.2008.tb00102.x

Metcalf, T.R. (1989). An imperial vision: Indian architecture and Britain's Raj. University of California Press.

Mridha, A.M.M.H. \& Khan, M.A. (2004). The Legacy of colonial architecture in Khulna city. Khulna University Studies, 4 (2), 713-24.

Nargis, P., Ismail, S., Utaberta, N., Yunos, M. Y. M., Ismail, N. A., \& Arifin, N. F. M. (2015). A review on the architectural styles of colonial buildings Bangladesh: case study on three prominent colonial establishment in Dhaka. Advances in Environmental Biology, 9(24), 6-11.

Naylor, S. (2010). The ethos of 'the Queenslander': a Journey into the art of building in North Queensland. (Refereed proceedings of the Tropics of the Imagination Conference, James Cook University, Cairns). eTropic: electronic journal of studies in the tropics, 9. https://doi.org/10.25120/etropic.9.0.2010.3424

Patra, A., \& Bhaskaran, P. K. (2016). Trends in wind-wave climate over the head Bay of Bengal region. International Journal of Climatology, 36(13), 4222-4240. https://doi.org/10.1002/joc. 4627

Rahaman, H. (2008). The Legacy of Colonial Buildings in Khulna City - An Approach to Digital Documentation. In M. Ioannides, A. Addison, A. Georgopoulos, \& L. Kalisperis (Eds). Proceedings of the 14th International Conference on Virtual Systems and Multimedia. Limassol, Cyprus.

Sanusi A.N.Z., Azmin A.K., Abdullah F., \& Kassim M.H. (2019) Climatic Adaptations of Colonial School Buildings in Malaysia. In Sayigh A. (Ed.) Sustainable Vernacular Architecture. Innovative Renewable Energy. Springer, Cham. https://doi.org/10.1007/978-3-030-06185-2 14

Shamsuddin, A. K. (1986), Khulna Shahorer Aadi Parbo. Eastern Press.

Shannon, K. (2014). Beyond Tropical Regionalism: The Architecture of Southeast Asia. In E. G. Haddad \& D. Rifkin (Eds.), A Critical History of Contemporary Architecture: 1960-2010 (pp. 359-377). Ashgate Publishing Ltd.

Singh, M. K., Mahapatra, S., \& Atreya, S. K. (2011). Solar passive features in vernacular architecture of North-East India. Solar Energy, 85(9), 2011-2022 https://doi.org/10.1016/j.solener.2011.05.009

Sobhan, R., Saha, K., \& Nahyan, M. (2013). The architecture of 'Bangla Batton' houses in Sylhet city: An ethnographical study on vernacular house form. In Proceedings of CAA Dhaka General Assembly \& Conference. Dhaka, Bangladesh. http://www.comarchitect.org/wp-content/dhaka-2013/pdf file/cd-\%20tp\%2006.pdf 
eTropic 19.2 (2020) Special Issue: Sustainable Tropical Urbanism

Muhaiminul Islam is an Architect, Partner and founding member at Clayscape Design Workshop a small architecture studio that conducts research and design projects focused on tropical deltaic issues and beyond. He is also a Lecturer in the Department of Architecture at Northern University of Business and Technology Khulna. He has a Bachelor in Architecture (B.Arch) from the Architecture Discipline of Khulna University as well as a Master of Science in Human Settlements (MScHS) from the same institution. His Master's Research topic was the impact of spatial configuration on students' social interaction in university academic buildings and his Bachelor Thesis topic analysed integrating heritage buildings of Natore town with cultural-ecological landscapes from a heritage trail approach. In parallel, he is working with Riverine Architecture Studio led by Ar. Sharif Jahir Hossain and Built Environment Consultant at Stha-Kalpa Architects. His research interests are design philosophy, learning space design, architectural history and heritage, climate resilience, housing and tropical architecture.

Hasan Muntasir is currently working as Lecturer in the Department of Architecture at Northern University of Business and Technology Khulna. He completed his Bachelor in Architecture from Bangladesh University of Engineering \& Technology (BUET). His Bachelor thesis topic was entitled 'Transcendency between a river and a city: A case of Rupsha and Khulna'. He has also conducted research work in space re-evaluation and informal settlement. His research interests are urban design, sustainability, architectural history and heritage, space and environmental issues. 